\title{
Pengaruh Kepemimpinan, Motivasi Kerja, Pelatihan dan Pengembangan Terhadap Kinerja Karyawan di Badan Perencanaan Pembangunan, Penelitian dan Pengembangan Kabupaten Bintan
}

\author{
Fanny Hidayati Eka Putri, Fatahurrazak
}

Fakultas Ekonomi Universitas Maritim Raja Ali Haji, Tanjungpinang, Kepulauan Riau, Indonesia

\begin{abstract}
ABSTRAK : Secara garis besar tujuan dari penelitian ini adalah untuk mengetahui apakah kepemimpinan, motivasi kerja, pelatihan dan pengembangan berpengaruh terhadap kinerja karyawan di Badan Perencanaan Pembangunan, Penelitian dan Pengembangan Kabupaten Bintan. Populasi dalam penelitian ini adalah seluruh karyawan Badan Perencanaan Pembangunan, Penelitian dan Pengembangan Kabupaten Bintan, dengan jumlah sampel sebanyak 42 karyawan PNS. Metode penelitian yang digunakan adalah deskriptif dengan pendekatan kuantitatif yang berupa studi kasus.. Hasil pengujian menunjukkan bahwa Kepemimpinan berpengaruh positif terhadap Kinerja Karyawan, Motivasi Kerja berpengaruh positif terhadap Kinerja Karyawan, Pelatihan dan Pengembangan berpengaruh positif terhadap Kinerja Karyawan, Kepemimpinan, Motivasi Kerja, Pelatihan dan Pengembangan berpengaruh secara simultan terhadap Kinerja Karyawan.
\end{abstract}

Kata Kunci: Kepemimpinan, Motivasi Kerja, Pelatihan dan Pengembangan, Kinerja Karyawan

Email Address : fatahurrazak@umrah.ac.id

\section{PENDAHULUAN}

Sumber daya manusia merupakan hal terpenting yang dimiliki suatu organisasi, salah satu implikasinya adalah bahwa investasi terpenting yang mungkin dilakukan oleh suatu organisasi adalah di bidang sumber daya manusia (Handoko, 2003). Tanpa dukungan kualitas sumber daya manusia yang terlibat didalamnya, peran pimpinan terhadap bawahan akan mempengaruhi berhasil tidaknya suatu tujuan. Oleh karena itu Pemimpin merupakan tokoh sentral yang dapat menaikkan kinerja bawahannya.

Kinerja adalah merupakan hasil keseluruhan pekerjaan secara kuantitas maupun kualitas yang telah dilakukan seorang pegawai dalam mencapai apa yang menjadi tujuan suatu lembaga atau instansi. Variabel kinerja diukur atau dinilai dengan indikator kuantitas dan kualitas hasil kerja. Menurut Budi Setiyawan dan Waridin (2006) kinerja karyawan merupakan hasil atau prestasi kerja karyawan yang dinilai dari segi kualitas maupun kuantitas berdasarkan standar kerja yang ditentukan oleh pihak Institusi.

Kepemimpinan sebagai suatu konsep manajemen di dalam kehidupan organisasi yang mempunyai kedudukan strategis dan merupakan gejala sosial yang selalu diperlukan dalam kehidupan kelompok.

Kepemimpinan memiliki kedudukan strategis karenakepemimpinan merupakan titik sentral dan dinamisator seluruh proses kegiatan organisasi. Sehingga kepemimpinan 
mempunyai peranan sentral di dalammenentukan kebijakan dalam organisasi sesuai sumber-sumber yang ada. Pada sebuah organisasi pemerintahan, kesuksesan atau kegagalan dalam pelaksanaan tugas dan penyelenggaraan pemerintahan, dipengaruhi oleh kepemimpinan, melalui kepemimpinan dan didukung oleh kapasitas organisasi pemerintahan yang memadai, maka penyelenggaraan tata pemerintahan yang baik (Good Governance) akan terwujud, sebaliknya kelemahan kepemimpinan merupakan salah satu sebab keruntuhan kinerja birokrasi di Indonesia (Istianto, 2009).

Kepemimpinan meliputi proses mempengaruhi dalam menentukan tujuan organisasi, memotivasi perilaku pengikut untuk mencapai tujuan, mempengaruhi untuk memperbaiki kelompok dan budayanya.

Selain itu juga mempengaruhi interpretasi mengenai peristiwa-peristiwa para pengikutnya, pengorganisasian, dan aktivitas-aktivitas untuk mencapai sasaran memelihara hubungan kerja sama dan kerja kelompok, perolehan dukungan, dan kerja sama dari orang-orang di luar kelompok atau organisasi (Veithzal Rivai dan Dedy Mulyadi, 2012:2).

Motivasi terbentuk dari sikap (attitude) pegawai dalam menghadapi situasi kerja di organisasi. Motivasi merupakan kondisi atau energi yang menggerakkan diri pegawai yang terarah atau tertuju untuk mencapai tujuan organisasi perusahaan. Sikap mental pegawai yang positif terhadap situasi kerja itulah yang memperkuat motivasi kerjanya untuk mencapai kinerja maksimal.

Motivasi adalah suatu usaha sadar untuk mempengaruhi perilaku seseorang agar mengarah tercapainya tujuan organisasi Barelson dan Steiner dalam Wahjosumidjo (1992:178). Jadi, dapat diartikan motivasi menurut Barelson dan Steiner didorong keadaan jiwa dan sikap mental manusia yang memberikan energi, mendorong untuk melakukan kegiatan dan ke arah mencapai kebutuhan yang memberi kepuasan.

Menurut Hakim dalam Regina (2010) motivasi adalah dorongan, upaya dan keinginan yang ada di dalam diri manusia yang mengaktifkan memberi daya serta mengarahkan perilaku untuk melaksanakan tugas-tugas dengan baik dalam lingkup pekerjaannya.

Berdasarkan pengertian dari beberapa ahli dapat disimpulkan motivasi merupakan respon pegawai terhadap sejumlah pernyataan mengenai keseluruhan usaha yang timbul dari dalam diri pegawai agar tumbuh dorongan untuk bekerja dan tujuan yang dikehendaki oleh pegawai tercapai.

Menurut Desimone (Randi, 2016:3-4) pelatihan merupakan training involves a process of providing KASs (Knowledge, Skill, ability, and others) specific to a particular taks or job atau dengan kata lain pelatihan memperbaiki penguasaan tertentu, terinci dan rutin untuk pekerjaan sekarang.

Pengembangan SDM adalah segala aktifitasyang dilakukan oleh organisasi dalam memfasilitasi pegawai agar memiliki pengetahuan, keahlian, dan sikap yang dibutuhkan dalam menangani pekerjaan saat ini atau akan datang.

Berdasarkan pendapat di atas dapat di simpulkan bahwa pelatihan merupakan suatu upaya untuk meningkatkan pengetahuan, kemampuan karyawan atau pegawai yang bertujuan untuk menciptakan karyawan atau pegawai yang berkualitas dari sebelumnya. Jadi dapat di simpulkan juga bahwa pengembangan merupakan proses yang di lakukan oleh organisasi untuk menciptakan pegawai-pegawainya yang berkualitas dan mempunyai keahlian di bidang pekerjaan, supaya dapat mencapai tujuan organisasi tersebut secara efisien. Menurut Rachmawati (2015), pelatihan merupakan wadah lingkungan bagi karyawan, di mana mereka memperoleh atau mempelajari sikap, kemampuan, keahlian, pengetahuan, dan perilaku spesifik yang berkaitan dengan pekerjaan.

Menurut Rivai dan Sagala (2015), pelatihan adalah proses secara sistematis mengubah tingkah laku pegawai untuk mencapai tujuan organisasi. Pelatihan berkaitan dengan keahlian dan kemampuan 
pegawai untuk melaksanakan pekerjaan saat ini. Berdasarkan pendapat para ahli diatas dapat disimpulkan bahwa pelatihan kerja adalah sebuah proses untuk meningkatkan kompetensi karyawan dan dapat melatih kemampuan, ketrampilan, keahlian dan pengertahuan karyawan guna melaksanakan pekerjaan secara efektif dan efisien untuk mencapai tujuan disuatu perusahaan.

Menurut Stone (dalam Kadarisman 2012) menyatakan bahwa Pengembangan karir karyawan adalah proses dan kegiatan mempersiapkan seorang karyawan untuk menduduki jabatan dalam organisasi atau perusahaan, yang akan dilakukan di masa mendatang. Dengan pengembangan tersebut tercakup pengertian bahwa perusahaan atau manajer SDM tersebut telah menyusun perencanaan sebelumnya tentang cara-cara yang perlu dilakukan untuk mengembangkan karir karyawan selama ia bekerja di perusahaan tersebut.

Menurut Dubrin (dalam Mangkunegara, 2013) mengemukakan bahwa pengembangan karir adalah aktivitas kepegawaian yang membantu pegawaipegawai merencanakan karir masa depan mereka di perusahaan agar perusahaan dan pegawai yang bersangkutan dapat mengembangkan diri secara maksimum.

Berdasarkan uraian pernyataan tersebut penulis dapat menyimpulkan bahwa pengembangan karir seorang pegawai atau karyawan perlu dilakukan karena seorang pegawai bekerja dalam suatu organisasi tidak hanya ingin memperoleh apa yang dimiliki hari ini, tetapi juga mengharapkan adanya perubahan, kemajuan, dan adanya kesempatan yang diberikan kepadanya untuk maju ke tingkat yang lebih tinggi dan lebih baik.

Bernardin (2001,143) dalam Sudarmanto (2009:8) kinerja merupakan catatan hasil yang diproduksi (dihasilkan) atas fungsi pekerjaan tertentu atau aktivitas-aktivitas selama periode waktu tertentu. Sehingga kinerja merupakan suatu hasil yang dicapai seseorang menurut ukuran yang berlaku untuk pekerjaan yang bersangkutan.

Peningkatan kinerja karyawan akan membawa kemajuan bagi Institusi untuk dapat bertahan dalam melakukan pelayanan terhadap masyarakat. Oleh karena itu upaya-upaya untuk meningkatkan kinerja karyawan merupakan tantangan pemimpin yang paling serius karena keberhasilan untuk mencapai tujuan tergantung pada kualitas kinerja sumber daya manusia yang ada didalamnya. Kepemimpinan merupakan kemampuan untuk mempengaruhi kelompok menuju pencapaian tujuan yang telah ditentukan. Kepemimpinan berpengaruh kuat terhadap kemajuan organisasi. Kualitas pemimpin sering dianggap sebagai faktor terpenting yang menentukan keberhasilan suatu organisasi.

Pemimpin adalah orang yang mengemban tugas dan tanggung jawab untuk memimpin dan bisa mempengaruhi orang yang dipimpinnya. Sosok ini mempunyai tugas dan kewajiban untuk memberi perlindungan dan bantuan secara pribadi dan mengelola kegiatan agar dapat mencapai tujuan yang sudah diprogramkan. Pemimpin yang efektif sanggup mempengaruhi para pengikutnya untuk mempunyai optimisme yang lebih besar, percaya diri, serta komitmen pada tujuan organisasi yang telah ditentukan.

Motivasi merupakan usaha sadar untuk mempengaruhi perilaku seseorang agar mengarah pada tercapainya tujuan organisasi yang telah ditentukan. Motivasi menjadi sangat penting dalam pencapaian kinerja pegawai. Motivasi berdampak pada seseorang atau individu untuk melibatkan diri pada kegiatan dan pekerjaan yang mengarah pada tujuan sebagai kepuasan. Motivasi yang diberikan oleh pimpinan sangat menentukan,keberhasilan sebuah lembaga atau instansi sangat ditentukan dari motivasi yang diberikan kepada pegawainya. Menurut Robbins dan Judge (2015) motivasi didefinisikan sebagai proses yang menjelaskan mengenai kekuatan, arah dan ketentuan seseorang dalam upaya untuk mencapai tujuan.

Kekuatan menggambarkan seberapa kerasnya seseorang dalam berusaha. Ketekunan mengukur berapa lama seseorang dapat mempertahankan upayanya. Para individu yang termotivasi akan bertahan 
cukup lama dengan tugasnya untuk mencapai tujuan mereka.

Menurut Malthis (2006:114), motivasi adalah keinginan dalam diri seseorang yang menyebabkan orang tersebut bertindak. Biasanya orang bertindak karena suatu alasan untuk mencapai tujuan.

Memahami motivasi sangatlah penting karena kinerja, reaksi terhadap kompensasi dan persoalan sumber daya manusia yang lain dipengaruhi dan mempengaruhi motivasi. Pendekatan untuk memahami motivasi berbeda-beda, karena teori yang berbeda mengembangkan pandangan dan model mereka sendiri. Pencapaian tujuan organisasi tergantung pada kinerja karyawannya. Jika sebuah perusahaan menginginkan keunggulan bersaing melalui sumber daya manusia (SDM), maka harus memuat konsep pelatihan dan pengembangan SDM secara kontinyu. Pelatihan dan pengembangan sangat penting bagi karyawan dan organisasi agar lebih efektif (Devi \& Shaik, 2012).

\section{METODOLOGI}

Metode yang digunakan dalam penelitian ini yaitu metode deskriptif dengan pendekatan kuantitatif yang berupa studi kasus. Penelitian kuantitatif adalah suatu proses menemukan pengetahuan yang menggunakan data berupa angka sebagai alat menganalisis keterangan mengenai apa yang ingin diketahui.(Kasiram (2008: 149) dalam bukunya Metodologi Penelitian Kualitatif dan Kuantitatif).

Menurut Sugiyono (2013:13) merupakan penelitian berlandaskan pada filsafat positivisme, yang digunakan untuk mempertimbangkan pada populasi atau sampel khusus, teknik pengambilan sampel yang dilakukan pada umumnya secara acak, bertemu data menggunakan instrument penelitian, analisis data yang bersifat kuantitatif/statistic yang memiliki tujuan untuk lanjut ke hipotesis yang telah ditentukan.

Jadi disini dapat disimpulkan bahwa penelitian deskriptif kuantitatif merupakan penelitian yang memusatkan pada masalah-masalah actual dan fenomena yang sedang terjadi pada saat penelitian berlangsung dengan bentuk hasil penelitian dengan berupa angka-angka dan deskripsi yang memiliki makna.

Menurut Margareta (2013), tujuan dari penelitian deskriptif dengan pendekatan kuantitatif yaitu untuk memperjelas suatu situasi yang hendak diteliti dengan dukungan studi keperpustakaan sehingga dapat lebih memperkuat analisis penelitian dalam penarikan kesimpulan.

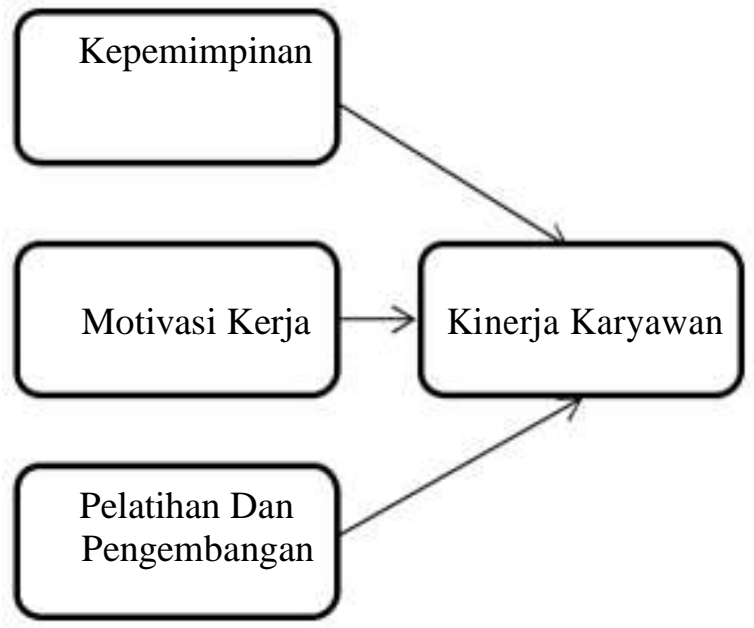

\section{HASIL DAN PEMBAHASAN}

\subsection{Hasil}

Populasi adalah wilayah generalisasi yang terdiri atas objek atau subyek yang mempunyai kualitas dan karakteristik tertentu yang ditetapkan oleh peneliti untuk dipelajari dan kemudian ditarik kesimpulannya (Sugiyono, 2013 : 80). Populasi dalam penelitian ini adalah seluruh karyawan Badan Perencanaan, Penelitian, dan Pengembangan Kabupaten Bintan.

Metode penentuan sampel dalam penelitian ini adalah purposive sampling. Purposive sampling adalah teknik penentuan sampel dengan pertimbangan tertentu (Sugiyono, 2013 : 85). Sampel dalam penelitian ini adalah karyawan PNS yang berjumlah sebanyak 42 orang.

Pengukuran uji validitas dapat dilakukan dengan membandingkan nilai rhitung dengan rtabel sig. yang dimana rhitung > rtabel maka pengujian validitas tersebut 
valid. Menurut Ghozali (2016:97), uji statistik t pada dasarnya menunjukkan seberapa jauh pengaruh satu variabel independen secara individual dalam menerangkan vaiasi

variabel dependen. Tingkat signifikansi yang digunakan sebesar 5\% dengan derajat kebebasan df $=(\mathrm{n}-\mathrm{k}-1)$, dimana (n) adalah jumlah observasi dan (k) adalah jumlah variabel. Uji ini dilakukan dengan membandingkan signifikansi thitung dengan ttabel dengan ketentuan :

1. Jika thitung < ttabel atau -thitung > ttabel, dan tingkat signifikansi $>0.05$, maka H0 diterima dan $\mathrm{Ha}$ ditolak (tidak ada pengaruh signifikan).

2. Jika thitung $>$ ttabel atau -thitung <-ttabel, dan tingkat signifikansi $<0.05$, maka H0 ditolak dan Ha diterima (ada pengaruh signifikan).
Analysis of Variance (ANOVA) merupakan metode untuk menguji hubungan antara satu variabel dependen dengan satu atau lebih

variabel independen (Ghozali 2013:68). Hasil uji statistik F dilihat dari table ANOVA dalam kolom sig. jika probabilitas $<0,05$, maka dapat dikatakan terdapat pengaruh yang

signifikan secara bersama-sama variabel bebas terhadap variabel terikat dan model regresi bisa dipakai untuk memprediksi variabel terikat. Atau jika nilai signifikansi > 0,05 maka tidak terdapat pengaruh yang signifikan secara bersama-sama antara variabel bebas terhadap variabel terikat.

Tabel 1 : Hasil Uji T

Coefficients $^{\mathrm{a}}$

\begin{tabular}{|c|c|c|c|c|c|c|c|c|}
\hline \multirow{2}{*}{\multicolumn{2}{|c|}{ Model }} & \multicolumn{2}{|c|}{ Unstandardized Coefficients } & \multirow{2}{*}{$\begin{array}{c}\begin{array}{c}\text { Standardized } \\
\text { Coefficients }\end{array} \\
\text { Beta }\end{array}$} & \multirow[b]{2}{*}{$t$} & \multirow[b]{2}{*}{ Sig. } & \multicolumn{2}{|c|}{ Collinearity Statistics } \\
\hline & & B & Std. Error & & & & Tolerance & VIF \\
\hline \multirow[t]{4}{*}{1} & (Constant) & 1,714 & 3,014 & & .569 & 573 & & \\
\hline & $\mathrm{X} 1$ &, 183 &, 063 &, 316 & 2,887 &, 006 &, 929 & 1,076 \\
\hline & $\times 2$ &, 492 &, 111 &, 488 & 4,420 &, 000 & .914 & 1,094 \\
\hline & $\times 3$ & 269 &, 112 &, 270 & 2,411 &, 021 &, 885 & 1,130 \\
\hline
\end{tabular}

a. Dependent Variable: $Y$

sumber : Diolah 
Tabel 3 : Hasil Uji F

ANOVA ${ }^{\text {a }}$

\begin{tabular}{|ll|r|r|r|r|r|}
\hline Model & \multicolumn{1}{c|}{$\begin{array}{c}\text { Sum of } \\
\text { Squares }\end{array}$} & df & Mean Square & \multicolumn{1}{c|}{ F } & Sig. \\
\hline 1 & Regression & 49,687 & 3 & 16,562 & 17,275 &, $000^{\mathrm{b}}$ \\
& Residual & 36,432 & 38 &, 959 & & \\
& Total & 86,119 & 41 & & & \\
\hline
\end{tabular}

a. Dependent Variable: $Y$

b. Predictors: (Constant), $\times 3, \times 1, \times 2$

\section{Sumber : Diolah}

Menurut Ghozali (2016:95) Koefisien determinasi $\left(\mathrm{R}^{2}\right)$ digunakan untuk mengukur seberapa jauh kemampuan model dalam menerangkan variasi variabel dependen. Nilai koefisien determinasi adalah antara 0 dan 1. Nilai $\mathrm{R}^{2}$ yang kecil berarti kemampuan variabel-

variabel independen dalam menjelaskan variasi variabel dependen amat terbatas. Nilai yang mendekati 1 berarti variabel-variabel independen memberikan hampir semua informasi yang dibutuhkan untuk memprediksi variasi variabel dependen. Berikut hasil dari uji Koefisien determinasi $\left(\mathrm{R}^{2}\right)$ :
Berdasarkan table di atas, dapat disimpulkan bahwa nilai Adjusted R Square nya sebesar 0.544

$\begin{array}{lcr}\text { atau } 54.4 \% & \text { dari } & \text { variabel } \\ \text { kepemimpinan, } & \text { motivasi } & \text { kerja, }\end{array}$ pelatihan dan pengembangan. Sedangkan sisanya $45.6 \%$ dijelaskan atau dipengaruhi oleh variabel-variabel lainnya yang tidak termasuk dalam model.

\subsection{Pembahasan}

Berdasarkan hasil analisis dan pembahasan yang telah dilakukan oleh peneliti secara parsial dan simultan variabel variabel bebas dalam model berpengaruh terhadap variabel terikat. Dalam instansi, kepemimpinan yang

baik dapat mempengaruhi meningkatkan kinerja dari karyawan itu sendiri, motivasi kerja yang baik dari diri sendiri maupun dari rekan kerja akan membuat karyawan semakin bersemangat dalam bekerja

Tabel 3 : Hasil Uji Determinan

Model Summary

\begin{tabular}{|c|c|c|c|c|c|c|c|c|c|}
\hline \multirow[b]{2}{*}{ Model } & \multirow[b]{2}{*}{$R$} & \multirow[b]{2}{*}{ RSquare } & \multirow[b]{2}{*}{$\begin{array}{l}\text { Adjusted R } \\
\text { Square }\end{array}$} & \multirow[b]{2}{*}{$\begin{array}{l}\text { Std. Error of } \\
\text { the Estimate }\end{array}$} & \multicolumn{5}{|c|}{ Change Statistics } \\
\hline & & & & & $\begin{array}{l}\text { RSquare } \\
\text { Change }\end{array}$ & F Change & difl & $d f 2$ & $\begin{array}{l}\text { Sig. F } \\
\text { Change }\end{array}$ \\
\hline 1 & $760^{2}$ & 577 & 544 & 979 & 577 & 17,275 & 3 & 38 &, 000 \\
\hline
\end{tabular}

a. Predictors: (Constant), X3, X1, X2

b. DependentVariable:Y 
dan dapat meningkatkan kinerja karyawan, mendapatkan dan melakukan pelatihan dan pengembangan yang tepat dari instansi akan meningkatkan kinerja dan kualitas dari karyawan bersangkutan.

\section{Kesimpulan}

Dalam penelitian ini dapat disimpulkan bahwa kepemimpinan secara parsial berpengaruh terhadap kinerja karyaran; motivasi kerja secara parsial berpengaruh terhadap kinerja karyawan;,pelatihan dan pengembangan secara parsial erpengaruh terhadap kinerja karyawan; dan Kepemimpinan, motivasi kerja, dan pelatihan dan pengembangan secara simultan berpengaruh terhadap kinerja karyawan di Badan Perencanaan, Pembangunan, Penelitian dan Pengembangan Kabupaten Bintan.Saran dari penelitian ini yang masih terbatas pada tiga variable independen, diharapkan pada penelitian berikutnya dapat menambah variable lainnya sehingga akan dapat memberikan kesimpulan yang lebih objektif.

\section{Daftar Pustaka}

Daniati, Rina, (2019) "Pengaruh Pelatihan dan Pengembangan SDM Terhadap Kinerja Pegawai Dinas Pekerjaan Umum dan Penataan Ruang Kabupaten Merangin". Jambi. Jurnal Ekopendia: Jurnal Ekonomi dan Pendidikan e-ISSN: 2656-7210.

Fauzi, Imam, (2012) "Pengaruh Kepemimpinan dan Motivasi Kerja Terhadap Kinerja Karyawan di PT Djarum. Semarang. http://journal.unnes.ac.id/sju/index .php/maj.

Fizia, Nurul,; Muttaqijn, M.Imam, (2018) "Pengaruh Pelatihan dan Pengembangan Karir Terhadap Kinerja Karyawan Pada PT Tri Megah Makmur". Tangerang. Volume 3 No.1 Tahun 2018. ISSN (p-2477-1546) dan (e-2581-1894)
Gardjito, Aldo Herlambang, et.al., (2014) "Pengaruh Motivasi Kerja dan Lingkungan Terhadap Kinerja Karyawan". Malang. Jurnal Administrasi Bisnis (JAB)|Vol. 13 No. 1 Agustus 2014|

Gede, I Komang, (2018) "Pengaruh Kepemimpinan Terhadap Kinerja Karyawan yang Dimoderasi Oleh Motivasi Kerja Pada BPR SeKecamatan Sukawati Gianyar. Bali. ISSN : 2337-3067. E-Jurnal Ekonomi dan Bisnis Universitas Udayana 7.4 (2018):1107-1134

Khoiri, Moh.;Oktavia, Nurul Rahma, (2017) "Pengaruh Kepemimpinan Terhadap Kinerja Karyawan Badan Pengawas Pemilu Kota Administrasi Jakarta Selatan. Jakarta.

Rahsel, Yoeyong, (2016) "Pengaruh Motivasi Kerja Terhadap Kinerja Pegawai Administrasi Pusat Universitas Padjajaran Bandung (Studi Pada Bagian Administrasi Umum UNPAD)". Lampung. Jurnal Manajemen Magister, Vol. 02. No.02, Juli 2016.

Rahinnaya, Rafdan; Perdhana, Mirwan Surya, (2016) "Analisis Pengaruh Pelatihan dan Pengembangan, Kompensasi serta Kompetensi Terhadap Kinerja Karyawan (Studi Pada PT. Pos Semarang)". Semarang. Volume 5, Nomor 3, Tahun 2016, Halaman 1-11 http://ejournal-

s1.undip.ac.id/index.php/dbr ISSN (Online): 2337-3792

Ramadhani, Danang Setya, (2016) "Pengaruh Kepemimpinan dan Motivasi Terhadap Kinerja Pegawai di Balai Pengembangan Kegiatan Belajar (BPKB) Daerah Istimewa Yogyakarta (DIY). Yogyakarta. Skripsi. 
Rego, Elvino Bonaparte Do, et.al (2017) "Pengaruh Kepemimpinan Terhadap Motivasi dan Kinerja Karyawan pada Direktorat Jendral Administrasi dan Keuangan, Kementerian Estatal Timor Leste. Bali. ISSN : 23373067 E-Jurnal Ekonomi dan Bisnis Universitas Udayana 6.11 (2017): 3731-3764

Saputri, Rahayu; Andayani, Nur Rahmah, (2018) "Pengaruh Kepemimpinan dan Motivasi Kerja Terhadap Kinerja Pegawai Pada Departemen Production di PT Cladtek BI-Metal Manufacturing Batam. Batam. Journal of Applied Business Administration Vol 2, No 2,September 2018, hlm. 307-316. e-ISSN:2548-9909.

Sukmasari, Hentry, (2011) “ Pengaruh Kepemimpinan, Motivasi, Insentif, Lingkungan Kerja, dan Kepuasan Kerja Terhadap Kinerja Pegawai Dinas Pengelolaan Keuangan dan Aset Daerah Kota Semarang. Semarang. Jurnal Tesis.

Sulaefi, (2017) "Pengaruh Pelatihan dan Pengembangan Terhadap Disiplin Kerja dan Kinerja Karyawan College of Agricultural Extension (STPP) in Magelang". Magelang. Vol. 5 No.1 2017

Widodo, Tri, (2010) "Pengaruh Lingkungan Kerja, Budaya Organisasi, Kepemimpinan Terhadap Kinerja (Studi pada Pegawai Kecamatan Sidoarjo Kota Salatiga)". Salatiga. Vol.3 No.5 Juli 2010.

Wijayanti, Dwi Wahyu, (2012) "Pengaruh Kepemimpinan dan Motivasi Kerja Terhadap Kinerja Karyawan Pada PT Daya Anugerah Semesta Semarang. Semarang. Skripsi.

Yopiana, (2014) "Pengaruh Pelatihan dan Pengembangan Karyawan Terhadap Kinerja Karyawan PT
Thamrin Brothers Palembang”. Palembang. 